\title{
Expansion of the Urban Area: The Fertilizers as one of the Challenges in the Coexistence of Rural and Urban Spaces.
}

\author{
Edina Schimanski ${ }^{1}$, Sandra M. Scheffer ${ }^{2}$, Reidy R. de Moura ${ }^{3}$
}

\begin{abstract}
:
This paper is part of a study carried out by researchers from the group of studies on environmental, gender and poverty issues, which is linked to the Applied Social Sciences Masters and Doctorate Program at Ponta Grossa State University. This is a qualitativequantitative study with characteristics of exploratory research, which addresses the social consequences of the use of fertilizers/pesticides to poor families living in the periphery of the city of Ponta Grossa in the South of Brazil. Triangulated data, obtained through field trips, interviews and participant observation, demonstrated the seriousness of the population contact with fertilizers. Theoretical studies on the theme identified that one of the most remarkable phenomena in the current Brazilian society is the speed of the urbanization process. Historically, the expansion of cities has been marked by the logics center-periphery, and in the last decades the transfer of groups of people has been noticed from the most central areas (due to economical and estate interests) to the most peripheral ones. It is important to consider the consequences of this phenomenon and how it is foreseen in the municipal planning, once it is in the rural-urban where the most significant natural resources are found, those which are vital to both the environmental balance and urban infra-structure systems. In the region of Ponta Grossa, Paraná State, South of Brazil, a process of strong junction between rural and urban has been observed. The evidence is that several areas and entire communities have developed very close to large areas of soybean, corn, wheat and other crops and thus, are totally exposed to the fertilizers used in those areas. Data collected also shows that the families living in those areas experience a routine of severe environmental, social and health problems without really understanding how serious this problem is.
\end{abstract}

Key words: urban expansion, urban-rural relationship, agricultural / community implication

\section{Introduction}

This text proposes a reflection on the urban expansion as one of the most remarkable events in the contemporary society in Brazil. Simultaneously, the rural zone has faced reduction, since it has been swallowed by the fast urban stretch from a spatial logic that takes as reference the center-periphery line.

The fast growth of urban areas and the social, environmental, economic and healthrelated implications resulting from the non-stoppable urbanization process has given rise to important elements regarding the Brazilian conjuncture analysis on social and urban planning in the last decades. The so-called transition areas between the rural and urban

\footnotetext{
Lecturer, Department of Social Work and Doctoral Program in Applied Social Sciences Ponta Grossa State University, Brazil

${ }^{2}$ Doctorate Student in the Urban Management Program at the Pontifical Catholic University of Paraná

3. Lecturer, Ponta Grossa State University, Brazil.
} 
spaces - which should strategically be areas of expansion reserve - have been the object of social struggle once they are involved in the urban problematic and its planning, both in socio-economic as well as in physical-territorial aspects.

Among ongoing problems related to reduction of the transition area between the rural and urban spaces, one of the most serious is the direct contact of people with pesticides used in the crop areas. As in many other parts of Brazil, the region of Ponta Grossa, more specifically the Campos Gerais - a geographical area situated in the South of Brazil in the State of Paraná, there has been a strong junction of the rural and urban spaces. This has provoked that many populated areas have to face large crop areas (soybean, corn, wheat, among others) and thus have been severely exposed to different agricultural inputs (chemical fertilizers, pesticides) used on the crops. The whole region is surrounded by large crop areas, mainly soybean, which demands a high load of fertilizers. Neighboring these crop areas, whole communities are exposed, which in general, besides facing specific problems of lack of basic infrastructure and poverty (a constant problem in the big center periphery) also struggle with the problems originated by the usual exposure to fertilizers and pesticides of all categories. In this sense, this study proposes an analysis of the social development, human gender and urban expansion, and their relation with environmental risk and poverty in the city of Ponta Grossa-Paraná-Brazil. The research portraits the consequences of fertilizers/pesticides use to the families that live in areas of transition between rural and urban spaces.

\section{The methodology of the research}

This paper is part of an exploratory study and it has a quali/quantitative character, and it is developed by social researchers from the Ponta Grossa State University linked to the research group 'Environmental issues, gender and poverty' which is linked to Social Work Department and Applied Social Sciences Post-graduation Program.

The research methodology adopted was based on data triangulation, which involves different spaces and people, as well as different times in the research. The triangulation also provides the researcher with multiple methods to obtain data and interpret the phenomenon such as interviews, observations, documents among other elements.

The research was carried out through participant observation and direct contact with communities that live on the border between the rural and urban areas. The environment was photographed and classified, in order to provide a description of the amplitude and dimension of the research locus. Also, semi-structured interviews were carried out with part of the population in order to obtain data on how these people realize the use of fertilizers/pesticides so close to the communities where they live, as well as the consequences brought by this situation. In addition to that, several documents such as regulations, mainly environmental, were analyzed in the development of the research.

The table below summarizes this research according to Minayo (2005): 


\section{Table 1 - Research steps and description}

\begin{tabular}{|c|c|}
\hline STEPS & DESCRIPTION \\
\hline $\begin{array}{l}\text { Establishing the } \\
\text { object and } \\
\text { referential } \\
\text { question }\end{array}$ & $\begin{array}{l}\text { First step of the research. The object portraits the process of problematic and } \\
\text { delimitation of a theme. After defining the object of study and the problem, } \\
\text { objectives, theoretical background methodology and the research schedule are } \\
\text { defined. }\end{array}$ \\
\hline $\begin{array}{l}\text { Bibliography } \\
\text { and reference } \\
\text { material }\end{array}$ & $\begin{array}{l}\text { The information sources might be oral, documental and bibliographic. The } \\
\text { oral ones rely on the involvement of individuals representative of the research } \\
\text { context selected based on quantitative and/or qualitative criteria. The } \\
\text { documents might be institutional (private, governmental), historical or } \\
\text { personal. The bibliography allows the reconstruction of core concepts, both } \\
\text { theoretical and methodological, as well as the categories that will inform the } \\
\text { analysis of the empirical data. }\end{array}$ \\
\hline $\begin{array}{l}\text { Definition of } \\
\text { instruments for } \\
\text { the primary and } \\
\text { secondary } \\
\text { information } \\
\text { collection. }\end{array}$ & $\begin{array}{l}\text { Identification and elaboration based on the theory, data information and } \\
\text { statement collection procedures. }\end{array}$ \\
\hline $\begin{array}{l}\text { Field work } \\
\text { organization } \\
\text { and } \\
\text { development. }\end{array}$ & $\begin{array}{l}\text { Data collection, when the necessary information is obtained to be analyzed } \\
\text { later. It requires clarity regarding the research question and objectives aimed at. } \\
\text { It is necessary to provide a detailed description of the empirical reality to be } \\
\text { studied as well as of the context in which the relations between individuals } \\
\text { develop, their interactions, socio-economic, cultural and historical background, } \\
\text { as well as singular aspects which are present in the main characteristics of the } \\
\text { object of study. This is when the previously selected instruments are tested and } \\
\text { applied, information is registered (field diary, footage, transcriptions, photos, } \\
\text { etc.) and documents related to the research project are surveyed. }\end{array}$ \\
\hline $\begin{array}{l}\text { Analysis of the } \\
\text { information } \\
\text { gathered. }\end{array}$ & $\begin{array}{l}\text { "It consists of the data ordination, classification and the analysis. It tries to } \\
\text { compare the general and specific objectives and results [...]"(Minayo et al, } \\
2005, \text { p.43). } \\
\text { When quantitative analysis is carried out it means designing tables, typing } \\
\text { information, categorizing, producing simple statistics and crossing } \\
\text { information. When the analysis is qualitative, analytical categories are built up. }\end{array}$ \\
\hline Final report & Research report. It is when the results obtained are exposed. \\
\hline Return & $\begin{array}{l}\text { Return to the ones directly or indirectly involved in the research through } \\
\text { different strategies of disclosure, information and socialization of the research } \\
\text { results. }\end{array}$ \\
\hline
\end{tabular}

Based on and adapted from Minayoet al. (2005, p. 36-46)

The method triangulation, according to Ferreira, Schimanski and Bourguignon (2012,p.148) "...imposes challenges to the researchers, among which it is important to bighlight the interdisciplinarity, the dialogue between qualitative and quantitative approaches and the construction of research methodological procedures that apprehend the phenomena in a creative and at the same time strict way so that singular expressions are spotted in contexts marked by dynamics and deep social and bistorical transformations". [authors' translation] 


\section{Discussion}

- Urban expansion and rural space reduction: social and environmental consequences to the individuals in the community

Analyzing how the urban population is spatially organized allows the reflection on factors that permeate the urban social dynamics and on the contradictions that result from the relations developed in the urban space. The socio-spatial structuring dynamics expresses different forms of use and occupation of the urban soil, on which the society expresses its more diverse interests.

In the capitalist society, different social classes have different interests regarding space occupation. Several social actors co-exist in different areas such as the government, entrepreneurs, and estate agents, members of social and popular groups, among others, who express their needs and try to cater for them. Therefore, the urban space presents characteristics of a society of classes. This means that "spatial relations have a social nature, and their matrix is the society of classes and its processes"(Correa 2000, p.8)[authors' translation]. Thus, the space is simultaneously fragmented and articulated, and all parts keep spatial relations with each other. The center would be the link of this articulation and all the parts that belong to the urban space would be shaped according to the capitalist movement of economic, political and social development, as well as through the ideological legitimization. Correa (2000) also points out that the urban space is qualified as unequal and mutable. It is unequal because expresses the relation of classes which exist in the capitalist society and mutable due to its own social dynamics. Therefore, the urban space is an unequal and mutable complex, and the urban expansion is marked by several factors, among them the increase in the need for implementing new housing areas as well as more productive activity areas. The increase in urban areas occurs towards land that had so far been used for agriculture and cattle breeding, and these are incorporated to the urban space.

\section{- Urban and rural - elements in articulation}

Many times urban and rural are treated as opposed elements, however, even if there is legal delimitation of these areas, the intrinsic elements are in full connection. Thus, they are both "before anything else, points in articulation through relations and reciprocity that transform them in one"(Silva and Silva, 1989, p.13).[Authors' translation]

Castells (1983) emphasizes the need to overcome the dichotomy between rural and urban spaces, which is known as a traditional society and the modern society. The author proposes a way of thinking urbanization as a historical and social phenomenon, in which urban and rural are dimensions of the same societal phenomenon which is intertwined and is mutually determining one and other. Even if each part has its own particularities, rural and urban are integrated, as they are connected by the logic of production and accumulation of the capitalism.

For Scheffer (2003) even if the urban space is expanded over the rural space, the legal delimitation cannot be accounted for changes in lifestyle, where the urban style interacts with the production in agricultural activities and the rural with the whole urban life. This growing expansion or urban areas gradually provides the assimilation of everyday life spaces, the typical rural elements by the urban ones, as well as some of the urban elements by the rural ones. PontaGrossa is a city in the Paraná State and expresses this 
characteristic, in which the urban has been expanded over areas that used to be rural. The improvement of housing areas and the productive activities has shaped urban spaces which are on the border of large crop areas. Life in these spaces is not always peaceful, as there are several factors resulting from this interaction such as the consequences of fertilizer/pesticides to the lives of people who live in areas neighboring the crop areas.

\section{- $\quad$ Contrast areas}

In the history of Ponta Grossa, it is possible to verify several phases of development which contributed with the appearance and expansion of population such as the occupation by the cattle drovers of the past that crossed the region regularly, the construction of railways for the transport of the farm production and foreigner migration movements, which enlarged the demographic structure, among other factors. Its location in the Paraná State contributed to its development, as it is in a place that favors the dislocation of people from one city to another, mainly in the region of Campos Gerais. Therefore, it received investment in roads and railroads, which favored the population growth in the city, as it became an important road-railway junction in the State.

According to Brazilian Institute of Geography and Statistics -IBGE (2010), the city of Ponta Grossa has 311.611 inhabitants, however, it is important to highlight the contrast regarding urban/rural population and the spatial distribution of these people in the municipal area. From the total number of inhabitants in the city in $2010,304,733$ people lived in the urban area while 6,878 were in the rural area.

Therefore, the rural Ponta Grossa population corresponds to $2.21 \%$ of the total population and $97,79 \%$ of the population lives in the urban area. The space occupation, as represented in figure 1, also exposes an extended municipal area, however, the darkest area, defined as the urban area is relatively small in comparison to the general area, and it is in this smaller part that most of the population lives, that is the $97,79 \%$ of the population. This raises a question regarding how the current social-spatial configuration has affected the city and the population who live there. Thus, it is important to think about how the urban expansion occurred and how the population has dealt with their needs for health, education, housing and transport, among others.

Figure 1 - Map of Ponta Grossa presenting the total area of the city and the urban space area.

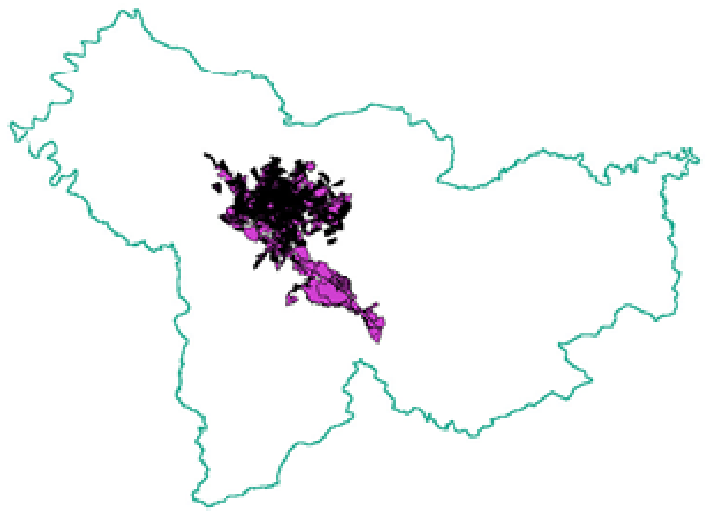

Source: Scheffer, 2003, p.46 apud Autarquia Municipal de Trânsito (Municipal TrafficAuthority) - Ponta Grossa-Paraná Brazil 
To Lowen Sahr (2001), Ponta Grossa presents a dynamic socio-spatial structure, initially with concentration of residents in the central area and along the railway. Later on, it started to expand to the periphery; however, it was the construction of housing centers that promoted the dislocation of residential areas to certain periphery regions. Therefore, the urban area of Ponta Grossa grew through major areas. Initially along the railway and later on along the main urban avenues that marked the expansion line center-periphery. With the more commercial occupation in the residential area, there was some enlargement of this area toward the periphery. The growth in these areas occurred with a very distinct intensity throughout the time and space, and as a result there are still large areas that have not been divided for occupation within the urban area, as well as areas with extensive agricultural activity. The housing programs, either from municipal companies or from private businesses have implemented several housing centers and sold pieces of land that have contributed to the urban expansion favoring the horizontal spread and the approximation between rural and urban areas. Therefore, the concentration of population in the periphery is provided with the construction of housing centers.

Some of the housing centers implemented by the municipal housing company provides horizontal expansion as well as the gradual transformation of the land use. As a result, many of the old areas that had agricultural use lost that function and became areas of urban use. This kind of expansion of the Ponta Grossa urban space has reflected in the necessity of the local government investment in infrastructure and urban equipment, due to the distance inter-neighborhoods and villages.

It is relevant to observe that in the last three years - between 2010 and 2013 - the implementation of housing programs has been accelerated, which is important to understand their repercussion on the urbanization process.

The urban profile has suffered great changes through the implementation of housing programs, which are located in the periphery, and several of those are in areas neighboring crop areas in which soybean, wheat and corn among other crops are grown. In such a scenario, the use of fertilizers/pesticides in the crops has become a socioenvironmental problem for the communities who live in these areas.

\section{- The pesticide as one of the challenges faced by the rural/urban interaction}

Pesticides, according to the Food and Agriculture Organization (FAO), regard the substances used to prevent, control and destroy plagues. This includes vectors of diseases and undesirable species (vegetal and animal) which cause damage to the food, agriculture products, wood and byproducts production and distribution processes. In the Brazilian law, pesticides are classified as physical, chemical or biological agents, which aid the growing, storage and processing of agriculture products. Such substances are used to transform the flora and fauna composition, in order to preserve them from harmful beings. According to the Federal Law number 7,802, article 2, item I:

Pesticides and similar are products and components of physical, chemical or biological processes destined to the production, storage and processing sector of agriculture products, in pasture, in the protection of native or planted forests and other ecosystems 
as well as in urban environments, water and industrial sector, whose aim is to alter the flora and fauna composition in order to preserve it from the harmful action of live beings which are considered harmful, as well as substances and products employed as defoliant, desiccant and growth stimulator and inhibitors.[Authors' translation]

According to BRAIBANTE and ZAPPE (2012), the pesticide category includes different substances as:
a) insecticides (insect control);
b) fungicides(fungi control);
c) herbicide (weed control);
d)fumigant (soilbacteriacombat);
e) algaecides (algaecombat);
f) bird repellent (bird combat);
g) anti-parasite (nematodecombat);
h) anti-snail (snailcombat)
i) acaricide (mitecombat);
j) growth regulators;
k) defoliants (undesirable leaves combat) and
l) desiccants.

(Adapted from BRAIBANTE and ZAPPE, 2012)

The Brazilian Association of Collective Health-ABRASCO report points out categorically the impacts on public health resulting from the intensive use of pesticides. In Brazil, the continuous use of these substances has reached several territories and different activities, people living around factories and farms, in addition to all consumers, who eat contaminated food (Rigotto et al., 2012, p. 12). The same report points to alarming data when it states that in all spaces or sectors of the agribusiness productive chain, there are proved human contamination, cancers diseases, deformity, skin diseases and breathing diseases cases, all resulting from pesticide and fertilizer contamination in water, air and soil.(Rigotto et al., 2012). More specifically, it is important to highlight, it calls attention initially to health as a life resource which comprises social and personal resources and which depends on social, cultural, economic and environmental conditions (Rigotto et al., 2012). Lack of health, or health-threatening situations harms directly the population, who many times not even realize the seriousness of the problem, due to their condition as users of these products - in many cases they are 'invisible' to the society.

The understanding of what health is might vary with people's different cultures, but there is a consensus that it has to do with democracy, education, work and freedom, and mainly with suitable sanitation conditions(Rigotto et al., 2012). This involves, without any doubt, good housing condition, healthy air, access to proper food to be consumed in a healthy way and basic infrastructure, as for example, efficient basic sanitation, water supply appropriate systems, good collection and disposition of sewage, garbage and recyclable material treatment, considering that the

Another important point regards the exposure to the environmental risk that whole communities experience. Either to chemical substances in the air or soil, or through the consumption of water and food, there is imminent risk that might result in 
significant damage to the health. However, it is not always possible to prove the association of the disease factor to the use of pesticides, as it can be seen in the excerpt below.

In most health problems with some environmental etiology, there are several factors influencing their appearance, including the exposure to environmental risks, but most of the time it is much more difficult to demonstrate this association incontestably. The association might occur through the clinical medicine, when there is a strong set of evidence associated to occupational/environmental exposure, which enables doctors, with the help of other professionals, to establish the link.(Rigotto et al., 2012, p. 33).

Therefore, it seems that it is not easy to establish a relation between health problems and environmental risk exposure. There are some alternatives, such as epidemiologic studies that can be carried out with the population in exposure, but their results are not always conclusive which make the analysis difficult. This is even more serious regarding the exposure due to the population living in areas close to regions of hazardous activities, in this case the epidemiological link is usually much more complex and difficult to be established. For example, the access to historical series of data regarding both environmental risks and people's health in specific communities is difficult to obtain. There is the singularity of each situation, as there might exist different risks and exposure contexts, and it is very complex to establish statistical associations which are absolute and irrefutable (Rigotto et al., 2012).

\section{The results of the research}

The triangulation of methods yielded significant results regarding the consequences of the use of pesticides to the population as it follows:

\section{- $\quad$ Face to face with large crops}

In the places that form Ponta Grossa region, people's report is that the use of chemical products is constant, mainly in soybean crops, as well as burn clearing between the crops, as it can be seen in Figures 3 and 4 below:

FIGURE 3: Jardim Três Rios e Manacás - Periphery of Ponta Grossa - PR.

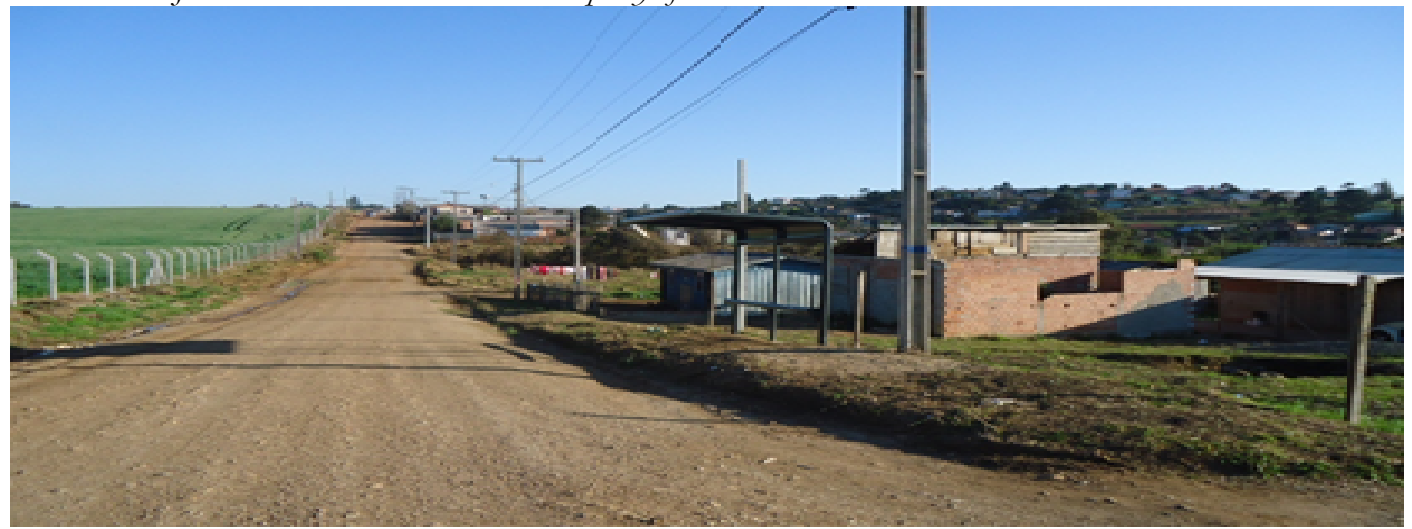

Source: students in the Social Work Course (2011) 


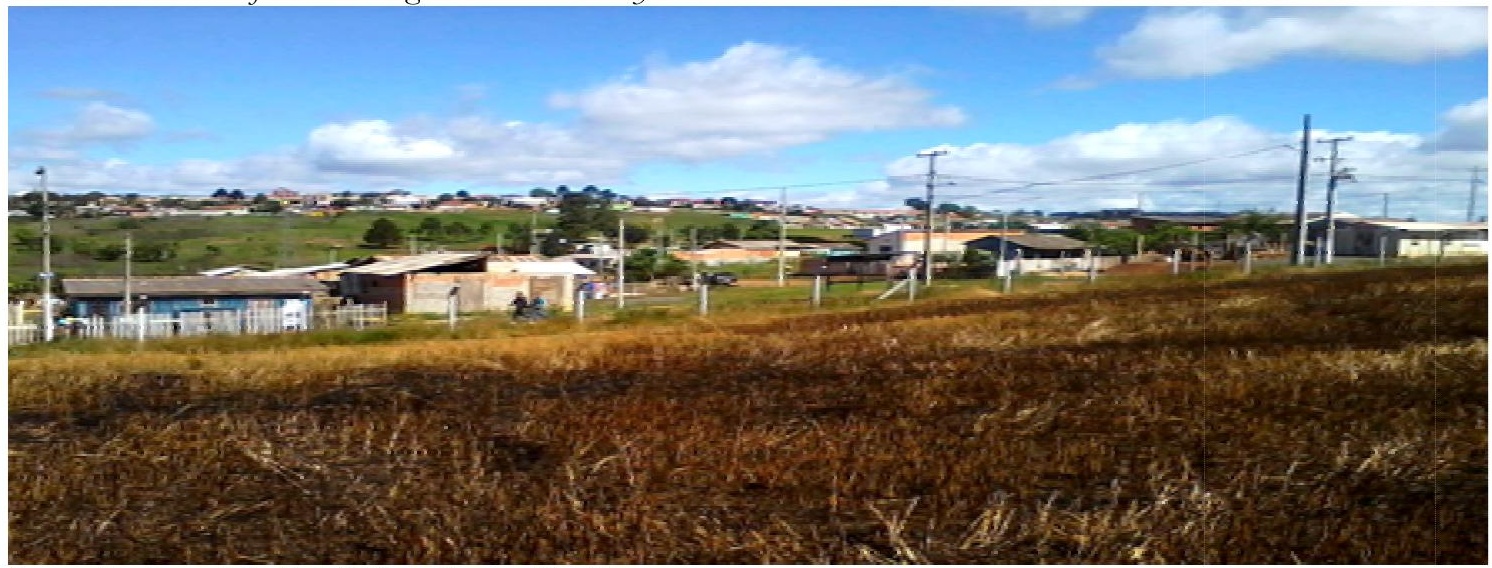

Source: Students of the Social Work Course (2011)

In general, in the communities, in the middle of the crop area, there are small rivers and paths that people use to get to other neighborhoods, or even in order to reach the school, the health center.

FIGURE 5: A resident of the neighborbood using one of the paths that crosses the crop area.

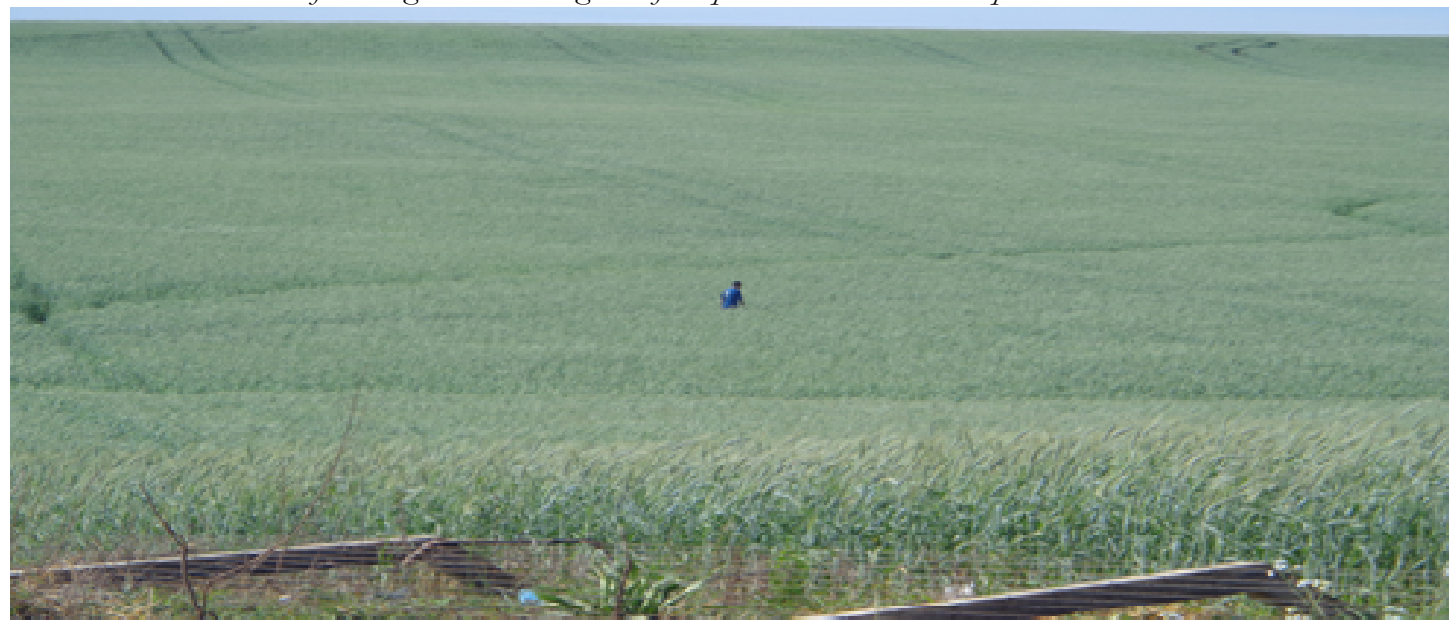

Source: Sandra Scheffer (2013)

The strong smell of chemical products, which according to the residents comes from the crop area when these products are applied, is one of the complaints in the communities. The residents also describe the difficulty people have to breathe, the burning feeling and itching in the nose and throat and headaches. Health, therefore, is harmed everyday due to the exposure to the chemical products.

Another relevant issue regards the perception that the families who live in these areas suffer constantly the presence of animals, including venomous ones. The residents also mentioned rat's occurrence. These animals appear to feed from the crop grains, and some even live in the small polluted rivers where rubbish accumulates. Many of these 
communities are crossed by a small river, which also receives crop remains. These rivers are marked by erosion and the destruction of the environment as a result of the human occupation pressure in a degrading form for both the rivers and the people who have to live there. Many families have no other alternative than to build precarious houses on the river banks, which means environmental risk imminent danger.

Another factor that deserves emphasis is the appearance of snails. These animals have become a plague in some communities once they come in hundreds at night covering whole walls in the houses - according to residents' reports. For them, there is a close relation between the appearance of snails in the houses and the crop area located opposite the community.

Finally, some remarks made by members of the families who live in the community near the crop area and their expression regarding the challenge that the use of pesticides poses to the urban/rural relation:

Ah, I think there it is impossible, because they put so much pesticides and things that are harmful. And I, for example, I have a baby, who is two years old, the baby cannot walk yet, and has a breathing problem, it's an abnormal heart murmur, so we have to keep the bouse closed when we are inside, we cannot leave the door open, or something like that, because if it is open you feel bad (Family 1)

The snails crossed [the street which is between the crop area and the first row of houses], we could see them on the windows, on the pavement, it was disgusting! I'm going to tell you, there were some as big as my hand. Now there aren't anymore. But in the past the streets had this bad smell, the cars drove on them and smashed them. It was really stinky on this road, mainly the low part. Nowadays, it reduced a lot, but I also used a lot of repellent on the yard, everything that people told me would repel them". (Family 2)

We can smell the pesticide. My busband has rbinitis; my son bad a very strong allergy, coincidently exactly when they applied the pesticide. One of my neighbors even left the place because of a very serious breatbing problem she had" (Family 3)

\section{Conclusions:}

Some of the actions regarding the housing area in Ponta Grossa, in its historical trajectory, show the influence that they had on the enlargement of the urban area, as, with the creation of new villages, the periphery is mainly expanded, favoring the horizontal spread of the city. The housing policy interferes in this reality presenting certain logic for the urban space occupation and at the same time is determined by this dynamics. It is in this context that the flexibility of soil division, which allows the city to define as urban areas, areas that lack minimal urban equipment.

Even with most of its population in the urban area, the city periphery borders present more rural characteristics, which deserve attention from the municipal government on the issue, planning and carrying out regulations such as, for example: the implementation of living fences (as ecological curtains) between areas; the definition of a certain limit to the beginning of the crop area on the borders; the inspection of pesticides use and their side effects on the elements that comprise the local environment. These rules might be set forth in the urban instruments in order to establish good coexistence of rural and urban spaces. 


\section{References}

BRAIBANTE, M.E. and ZAPPE, J. A.(2012) A química dos agrotóxicos. Revista Química Nova na Escola. (34) 1, p. 10-15, Retrieved August, 102013

CASTELLS, M.(1983) A questão urbana. Tradução de Arlene Caetano. Rio de Janeiro: Paz e Terra

CORREA, R.L.(2000) O espaço urbano. 4 ed. São Paulo: Ática

FAO (FoodandAgricultureOrganization). Agriculturaldatabase, 2003. Disponível em: http://www.fao.org.Retrieved August, 102013

FERREIRA, A., SCHIMANSKI, E. e BOURGUIGNON, J. (2012) A triangulação como recurso metodológico na pesquisa social. In: BOURGUIGNON, Jussara e OLIVERIA JUNIOR, Constantino (Eds.) Pesquisa em Ciências Sociais. Interfaces, debates e metodologias. Ponta Grossa, Toda Plavra Editora

INSTITUTO BRASILEIRO DE GEOGRAFIA E ESTATÍSTICA - IBGE. Estimativas projeções populacionais Municipais. (2010) Disponível em ftp://ftp.ibge.gov.br/Estimativas_Projecoes_Populacao/Estimativas_2012/estimativa_2012_mun icipios.pdf. Fromhttp://www.ibge.gov.br/home/, RetrievedSeptember, 082012.

INSTITUTO BRASILEIRO DE GEOGRAFIA E ESTATÍSTICA - IBGE . Resultados do Universo do Censo Demográfico (2010). Disponível em ftp://ftp.ibge.gov.br/Censos/Censo_Demografico_2010/Resultados_do_Universo/tabelas_pdf/ tab1.pdf fromhttp://www.ibge.gov.br/home/, RetrievedSeptember, 082012

LOWEN SAHR, C. (2001)Estrutura interna e dinâmica social na cidade de Ponta Grossa. In: DITZEL, Carmencita de Holleben Mello; LOWEN SAHR, Cicilian Luiza (eds.) Espaço e cultura. Ponta Grossa e os Campos Gerais. Ponta Grossa: Editora UEPG

RIGOTTO, R. M. et al. Dossiê Abrasco - Parte 3 (2012). Agrotóxicos, conbecimento científico e popular: construindo a ecologia de saberes. Porto Alegre, fromhttp://www.abrasco.org.br/UserFiles/File/ABRASCODIVULGA/2012/DossieAGT.pdf

RetrievedDecember, 02, 2012

MINAYO, M. C. de S., ASSIS, S. G. andSOUZA, E. R.(2005) Avaliação por Triangulação de métodos: abordagem de programas sociais. Rio de Janeiro: Editora Fiocruz

SCHEFFER, S.(2003)Espaço Urbano e Política Habitacional: uma análise sobre o Programa de Lotes Urbanizados da Prolar - Ponta Grossa. Dissertação de mestrado em Ciências Sociais Aplicadas. Ponta Grossa: UEPG,

SCHIMANSKI, E., COSTA, L.C., MOURA, R e SCHEFFER, S. (2013) Educação socioambiental, cidadania e emancipação comunitária no Jardim Três Rios e Manacás. Relatório de Projeto de Extensão[CD -Rom]Paraná: UEPG.

SILVA e SILVA, M. O.(1989) Politica Habitacional Brasileira - Verso e Reverso. São Paulo: Cortez. 
